\title{
Change management in information institutions
}

\author{
Gordana Dukić ${ }^{1}$, Darko Dukić ${ }^{2}$ and Goran Kozina ${ }^{3}$ \\ ${ }^{1}$ Department of Information Sciences, \\ Faculty of Humanities and Social Sciences \\ Josip Juraj Strossmayer University of Osijek \\ Lorenza Jägera 9, 31000 Osijek, CROATIA \\ ${ }^{2}$ Department of Physics \\ Josip Juraj Strossmayer University of Osijek \\ Trg Ljudevita Gaja 6, 31000 Osijek, CROATIA \\ ${ }^{3}$ University North in Varaždin \\ 104. brigade 3, 42000 Varaždin, CROATIA \\ e-mail: gdukic@ffos.hr (corresponding author); \\ darko.dukic@fizika.unios.hr; goran.kozina@unin.hr
}

\begin{abstract}
The purpose of this study is to examine how professionals employed in libraries, museums and archives assess changes and effectiveness of change management in their organisations. The intention is also to determine the underlying factor structure of the items representing their attitudes, and to explore the relationship between the perceived success in managing change and explanatory variables. This study involved a survey of 242 employees of Croatian information institutions. Descriptive statistics, factor analysis and ordinal logistic regression were employed to answer the research questions. The results show that respondents had a mildly positive attitude towards the changes that occurred in their institutions. They are largely aware of the importance and necessity of changes. However, the responses indicate that changes are not adequately managed. Three factors, which represent the underlying dimensions of the employees' perceptions, were determined in the analysis. It was also found that the factors reflecting attitudes towards change management practice and impact of change positively influence the assessment of the institution's success in managing change, while employees' awareness of the necessity of change, as well as gender, age, institution type and position in the management structure appear not to be strongly related to the outcome variable. Since only a few papers have examined the perception of change management by information professionals, the present study fills the gap in this area and contributes to a more comprehensive understanding of change management theory and practice.
\end{abstract}

Keywords: Changes; Change management; Information institutions; Information professionals; Attitudes.

\section{INTRODUCTION}

Changes are at the core of human society, and have been particularly prominent through technology advances in the past few decades. If organisations wish to survive and successfully develop in a dynamic and turbulent environment, they are bound to implement and manage changes. The focus on changes and their impact should therefore be the highest priority in any organisation. Given that resistance to change is immanent to human nature, one of the biggest challenges for today's managers at all levels is how to create a positive atmosphere for implementing the necessary changes. 
A number of approaches to the notion of change management can be found in the literature. Atkin and Brooks (2009) defined change management as a set of techniques that aid in evolution, composition and policy management of the design and implementation of an object or system. According to Shah and Harris (2010), change management represents the process of developing a planned approach to change in an organisation. Change management is also defined as a set of principles, techniques and prescriptions applied to the human aspects of executing major change initiatives in organizational settings (GriffithCooper and King 2010).

Carnall (2007) believes that modern organisations are confronted with several main dilemmas. One of them is the choice between change and stability. In a constantly changing world, organisations have to find the best balance between these opposites. Different factors can be drivers of change. Sharma (2008) speaks of external forces, such as political and economic factors, technological changes, government policies, globalisation and increased competition, as well as changing customer needs and preferences. According to Sharma, there are also internal forces, such as system dynamics, managerial and administrative processes, individual and group expectations, organisation design and structure, and technological changes. Paton and McCalman (2008) identified six major external changes that modern organisations are facing: a larger global market; recognition of the environment as an influencing variable; health consciousness as a permanent trend amongst all age groups; changes in lifestyle trends; the changing workplace which creates a need for non-traditional employees; and the knowledge asset of the company.

Changes can be more or less comprehensive, covering the entire organisation or a certain part of it. In that sense, Anderson and Anderson (2010) differentiated between three basic types of organisational change. The simplest one is developmental change, which represents the improvement of an existing condition that does not measure up to current or future needs. In general, the changes are not profound or radical and the impact on people is relatively mild. Transitional change is more complex, representing the required response to more significant shifts in the environment. While developmental change is focused on improving an existing skill, knowledge, practice and performance, transitional change requires the redesign of strategy, structures, systems, processes and technology. Transformational change is the most complex type of change, usually implemented when the survival of the organisation is at stake. To be successful, transformational change requires radical shifts in culture, behavioural and thinking patterns. In contrast with the first two types, the new state which should arise from the transformation process is usually quite uncertain.

If properly planned, managed and executed, changes can bring numerous benefits to an organisation (Dukić 2015). According to Lientz and Rea (2004), some of the key benefits are simplification of work, increased efficiency and improved management of the work, increased automation, increased revenue, simpler organisation, improved customer/supplier relations and improved employee morale. In principle, such benefits refer also to information institutions. Given their specific role and position in the society, these institutions should have a keen interest in implementing change. Changes are necessary if information institutions, such as libraries, museums and archives, are to respond successfully to their ever-increasing challenges. 


\section{INFORMATION INSTITUTIONS AND CHALLENGES OF CHANGE}

Information institutions can be defined in a straightforward way as organisations that collect, select, organise, preserve and distribute information products and/or services to an audience and present cultural and scientific riches they possess (Ruben 1993; Borgman 2002; Smiraglia 2014). Writing about changes in society and how they reflect on information institutions and education in today's world, Lasić Lazić (2010) concluded that the task of information institutions is to provide access to official publications and documents, guarantee the right to information and knowledge to all, promote and improve the use of public information sources, provide assistance in searching all kinds of documents and participate in building an information infrastructure. In a time of rapid and complex change, information institutions have to redesign the way they work. For example, they need to focus on audience engagement and experiences, put emphasis on enhancing knowledge and skills, promote collaborative partnerships, become embedded in community and act as a leader on community needs/issues, and appropriately combine tangible and digital content (Institute of Museum and Library Services 2009).

A company's employees play a crucial role in preparing and adapting information institutions for functioning in these new conditions. For this reason, special attention should be given to the education of librarians and information professionals (Robati and Singh 2013; Singh and Mehra 2013; Rasuli and Naghshineh 2014). In this context, AparacJelušić (2005) pointed out that education programmes need to observe recommendations given by professional bodies and reach a consensus regarding the core courses as a foundation on which elective modules are then built upon. To enhance the quality of education, systematic cooperation between institutions should be established, and the teaching process modernized through new approaches, including distance learning. Due to increasing and systematic usage of new technologies, the competencies of librarians and information professionals have to be constantly updated through life-long education programmes (Thomas, Satpathi and Satpathi 2010). Information institutions will be able to fulfil their mission and realize strategic goals only if they have a solidly educated, professional, motivated and highly responsible staff. At a time when change is the only constant, change management is without a doubt one of the key competencies that modern information professionals need to be successful in their job (Fisher 2001; Ammons-Stephens et al. 2009; Partridge et al. 2010; Dole 2013; Nazim and Mukherjee 2013).

\section{LITERATURE REVIEW}

In scholarly publications around the world, change and change management in information institutions are mostly viewed through the prism of adjusting their work and organisation to the intensive development of information and communication technologies (ICT). This issue seems to be central to most of the studies, whose most important conclusions are presented in this review section.

The world in which change is a constant - whose consequences are often hard to grasp offers numerous opportunities, but, at the same time, also raises concerns. According to Farrow (1997), this is particularly so in the information and library sector, and consequently many are feeling the pressures. Weldon (1983) concluded that the greatest changes have come from the post-industrial, information revolution and that the ultimate impact of the computer upon archives and archivists is unknown. To meet the challenges 
resulting from all the changes, archivists will have to work together more than they ever have in the past, and to master a range of managerial and administrative skills. Weldon believed that one of the greatest challenges archivists face could well be finding job satisfaction in solving the new archival management problems rather than in dealing firsthand with researchers or historical materials. Speaking of change management and chance, Anderson (1985) warned that the traditional methods for developing collecting policies did not work well in social history archives. Therefore, he described the process employed by an American archive institution to develop a viable collecting policy and to implement an active collecting program.

Storey (1995) examined the impact of information technology on management and organization of a Hong Kong university library. One of the conclusions is that the pressure for change is based on the dynamic relationship between many human and abstract elements. It is also acknowledged that automation is a catalyst for change. Penfold (2000) began his study with the claim that information services have always been under constant pressure to prove to management the value of their staff, services and existence. In that context, change management is a key extended skill which the information and library sector must acquire in order to take control of organizational information strategies and coordinate and drive the technologies.

Tam and Robertson (2002) pointed to several drivers of change in libraries and information services, such as developments in information technology and advances in telecommunications, the growth of the electronic economy, changing educational and learning environment, and changes in scholarly communication. The authors claimed that change had to be implemented in several areas, such as organisational structure, technology, tasks and people. Molaudi and Du Toit (2003) investigated the extent to which change was being managed in academic information services in South Africa. They conducted a survey of 21 directors of information services within the higher education system. Based on the responses, the authors concluded that technological innovation was seen as an opportunity in the South African academic information services. There were various reasons why planned changes had taken place, including the fact that the subordinates were largely involved in the change process, the managers motivated the staff to accept change, and the managers defined the change vision when initiating the change process, which clarified the future course of action.

Sandell (2003) focused on the changes faced by museums in a rapidly evolving environment. Some change-inhibiting factors were found to be entrenched attitudes within the sector, exclusive working practices, perceptions of museums, lack of progress, and limited workforce diversity. The issue of change management in museums was also addressed by Suchy (2004), who presented the results of a survey conducted in several states. She examined the attitudes of museum directors and their deputies and found that changes have serious implications for selection, career paths, leadership development initiatives and succession planning strategies.

Konings and Dekker (2005) described the process of change in a Dutch university library. The authors' experience indicates some important criteria for devising a new organisation: team work, disentanglement of processes which resulted in disentanglement of employee tasks, and decreasing the number of management layers. Pandya and Pandya (2010) found that change management tools are aimed at using new ideas that encourage library adaptation. Libraries managed in a traditional way lack the flexibility to adapt to environments characterized by continuous change. In the analysis of some major trends in 
library management, Biswas (2012) concluded that librarians need to handle change effectively to survive in today's environment. The future can be exciting and promising only for those libraries that are open to change. Adeyoyin, Imam and Bello (2012) emphasized the importance of change management in library information resources, which includes the preservation of digitized resources, as well as handling problems with digitization.

Bartlett (2012) gave an overview of several resources dealing with change management in libraries and concluded that this area is a fertile ground for further research. According to Buchanan (2012), successful change management in information and library services requires most of the following prerequisites: establishing a clear goal and defining all areas affected by the change, detecting the area that creates the biggest challenge so as to determine the next course of action, using outside assistance if necessary, and building your own team to conduct and monitor the transformation. Kamila (2013) emphasized the following challenges for librarians in the global digital age: the information explosion, ICT, growth and usage of web resources, use of digital resources, users' expectations, virtual learning environment and virtual educational institutions, the development of digital, virtual and hybrid libraries, as well as online bookshops and information services. The author concludes that change management is the only solution available to information professionals to overcome all the difficulties arising in the ever-changing environment in the ICT era.

With only a few exceptions, most of the cited authors spoke only theoretically about change management in information institutions. In contrast, the present paper is based on empirical research. As a special questionnaire was designed for this purpose, and similar research has not been conducted, the obtained results could not be compared to other studies.

\section{OBJECTIVES AND RESEARCH QUESTIONS}

Change management is of crucial importance for efficient and effective functioning of every organisation. Taking this as a starting point, the aim of the paper was to determine how professionals employed in Croatian libraries, museums and archives perceive change and change management. The study also strived to identify the factors underlying their attitudes and to determine variables associated with the assessment of institutions' success in managing change. In particular, the research aimed to answer the following questions:

a) How satisfied are the professionals employed in Croatian libraries, museums and archives with the changes that have occurred in their institutions?

b) How do they perceive different aspects of change management in their organizations and evaluate the institution's success in managing change?

c) Which factors are associated with their attitudes towards change and change management?

d) How are the latent constructs and socio-demographic characteristics related to the perceived success?

These issues have not received much attention so far. Therefore, one of the intentions of the paper was to bring this important topic to the forefront and lay the foundation for future research. 
Dukić, G., Dukić, D. \& Kozina, G.

\section{METHOD}

A two-part questionnaire was devised for the survey. In the first part, the respondents were asked to provide some basic information about themselves and the institution they were employed in. The second part consisted of items dealing with change and change management in information institutions.

The data were collected by means of an online questionnaire. Potential respondents were first sent an e-mail with the link to the questionnaire. Their e-mail addresses were obtained from the institutions' websites. There were two subsequent e-mail reminders, and a thank-you note to those who participated.

The target population were professionals from Croatian libraries, museums and archives. The research covered the employees of information institutions in all the Croatian counties and the City of Zagreb. According to the available data at the time of the survey (Croatian Bureau of Statistics 2012), 4419 professionals were employed in Croatian information institutions. An invitation to participate in the study was sent to 1000 professionals. The questionnaire was completed by 242 respondents, which is roughly one fourth of those who were initially contacted.

Among the respondents, 165 were library employees (68.2\%), 60 were employed in museums $(24.8 \%)$, and 17 in archives (7\%). The sample consisted of 188 women (77.7\%) and 54 men (22.3\%). In terms of information institutions and gender, the sample is a fair representation of the population (Croatian Bureau of Statistics 2012). The youngest respondent was 24 years old, and the oldest 64 . The average age of the respondents was 42.98 years with a standard deviation of 10.19 years. Out of all respondents, 143 (59.1\%) held a managerial role within the institution, and 99 (40.9\%) were employees who stated that they did not participate in management.

Descriptive statistics were used to describe the data. An exploratory factor analysis was conducted to uncover the latent structure of a set of variables, i.e. to determine the underlying dimensions. Factor scores were also calculated in the analysis. Ordinal logistic regression was then performed to examine the relationship between the independent variables (four socio-demographic characteristics and three factors) and the dependent variable (assessment of the institution's success in managing change). The level of significance was set at $p<0.05$.

\section{RESULTS AND DISCUSSIONS}

Within the questionnaire, respondents were asked to rate the following five aspects of change in the institution in which they were employed: organisational changes, technical and technological changes, human resources changes, changes of the premises, i.e. redesign of the working environment, and changes of the services offered by their information institution. The respondents rated their satisfaction with the changes on a five-point Likert scale $(1=$ Not at all satisfied, $2=$ Mostly dissatisfied, $3=$ Neither satisfied nor dissatisfied, $4=$ Mostly satisfied, $5=$ Completely satisfied). Descriptive statistics calculated on the basis of responses is given in Table 1. 
Table 1: Descriptive Statistics for Satisfaction Ratings Regarding Changes

\begin{tabular}{lcccr}
\hline \hline Aspects of Change & Mean & Median & Mode $\begin{array}{r}\text { Standard } \\
\text { deviation }\end{array}$ \\
\hline \hline Organisational changes & 3.35 & 4.00 & 4.00 & 1.14 \\
\hline \hline Technical and technological changes & 3.33 & 4.00 & 4.00 & 1.11 \\
\hline \hline Human resources changes & 3.05 & 3.00 & 3.00 & 1.13 \\
\hline \hline Changes of the premises & 3.14 & 3.00 & 4.00 & 1.26 \\
\hline \hline Changes of the services offered & 3.54 & 4.00 & 4.00 & 1.02 \\
\hline \hline
\end{tabular}

The descriptive statistics do not show any drastic differences between the five aspects of change. On average, the respondents gave the highest ratings to the changes of the services offered by their institution. Judging by the mean, they are slightly less satisfied with organisational changes and technical and technological changes. In these two cases, the median and the mean indicate that the respondents' attitude can be viewed as mildly positive. A more neutral attitude is exhibited towards changes of the premises and especially towards human resource changes. According to the results, it can be concluded that there is room for improvement when it comes to change management in Croatian libraries, museums and archives. Clearly, lack of funding is a serious limitation in any effort to implement technical and technological changes, as well as changes of the premises in terms of redesigning the offices and work space. Even so, the management of information institutions should be able to obtain funding from other sources, and avoid complete dependence on the central and/or local government. Donations and European Union funds might be a solution, especially at the time of crisis, but getting them requires a lot of effort by the management of information institutions. Thus, the management should work much harder on those changes that they can influence more easily. These are, for example, the changes of the services offered, organisational changes and changes regarding the personnel. The analysis shows that human resource changes are seen as the area where much more could have been done. Although insufficient finances are a limiting factor in employing new staff and providing additional training to the current staff, there are still areas of human resources that can be improved with modest means. Reorganisation of jobs, reassignment of employees within the information institution, and a performance reward system are some of the tools that are always at the management's disposal. Still, there is no doubt that changes related to personnel are usually the most complex and sensitive moves, and managers in Croatian information institutions are usually not trained in human resources management; rather, this is something they undertake alongside their regular tasks. Even in such circumstances, managers should find a way to motivate their subordinates to accept the planned changes. For this process to succeed, it is advisable to involve the employees from the very beginning and allow them to participate in the decision-making.

The respondents were given 14 questions, or statements, with regard to change and different aspects of change management in the institutions in which they were employed. Again a five-point Likert scale was used ( 1 = Strongly disagree, $2=$ Mostly disagree, $3=$ 
Dukić, G., Dukić, D. \& Kozina, G.

Neither agree nor disagree, $4=$ Mostly agree, $5=$ Strongly agree). Table 2 lists the descriptive statistics that were calculated on the basis of the obtained responses.

Table 2: Descriptive Statistics for Attitudes on Different Aspects of Change Management

\begin{tabular}{|c|c|c|c|c|}
\hline \multirow{2}{*}{$\begin{array}{l}\text { Item statement } \\
\text { By introducing changes the institution gains in importance } \\
\text { in the local community }\end{array}$} & \multirow{2}{*}{ Mean } & \multirow{2}{*}{$\begin{array}{r}\text { Median } \\
4.00\end{array}$} & \multicolumn{2}{|c|}{ Mode $\begin{array}{l}\text { Standard } \\
\text { deviation }\end{array}$} \\
\hline & & & 4.00 & 0.83 \\
\hline $\begin{array}{l}\text { Introducing changes has a significant impact on increasing } \\
\text { user numbers }\end{array}$ & 3.89 & 4.00 & 4.00 & 0.88 \\
\hline $\begin{array}{l}\text { Introducing changes has a significant impact on increasing } \\
\text { user satisfaction }\end{array}$ & 4.14 & 4.00 & 4.00 & 0.77 \\
\hline $\begin{array}{l}\text { Changes are necessary if the institution is to survive and } \\
\text { develop }\end{array}$ & 4.53 & 5.00 & 5.00 & 0.57 \\
\hline $\begin{array}{l}\text { Changes are inextricably connected with the work and } \\
\text { activities of the institution }\end{array}$ & 4.41 & 4.00 & 4.00 & 0.63 \\
\hline $\begin{array}{l}\text { Changes contribute to improving an institution's efficiency } \\
\text { and effectiveness }\end{array}$ & 4.12 & 4.00 & 4.00 & 0.79 \\
\hline $\begin{array}{l}\text { The institution's employees are actively involved in the } \\
\text { process of changes }\end{array}$ & 3.71 & 4.00 & 4.00 & 1.01 \\
\hline $\begin{array}{l}\text { Employees receive a clear explanation of the importance } \\
\text { and purpose of changes being introduced }\end{array}$ & 3.45 & 4.00 & 4.00 & 1.10 \\
\hline $\begin{array}{l}\text { The employees who contribute most to the process of } \\
\text { change are specially rewarded }\end{array}$ & 2.65 & 3.00 & 3.00 & 1.22 \\
\hline $\begin{array}{l}\text { The institution has devised a strategy for introducing } \\
\text { changes }\end{array}$ & 2.97 & 3.00 & 3.00 & 1.09 \\
\hline Changes are introduced according to a pre-set plan & 3.02 & 3.00 & 3.00 & 1.08 \\
\hline $\begin{array}{l}\text { In the process of changes, all parts of the institution are } \\
\text { actively cooperating with each other }\end{array}$ & 3.27 & 3.00 & 3.00 & 1.14 \\
\hline $\begin{array}{l}\text { The key role in change management is taken by the } \\
\text { management of the institution }\end{array}$ & 3.72 & 4.00 & 4.00 & 1.00 \\
\hline Much attention is given to reducing resistance to change & 3.11 & 3.00 & 3.00 & 1.03 \\
\hline
\end{tabular}

According to the mean, the respondents showed the highest agreement with the statement that changes are necessary if their institution is to survive and develop. It was only with this variable that the median and mode had the value 5 . Another statement receiving a high level of agreement was that changes are inextricably connected with the work and activities of the institution. A slightly lower average rating was given to the claim that changes contribute to improving an institution's efficiency and effectiveness. These responses indicate that professionals employed in Croatian libraries, museums and archives are largely aware of the fact that changes are important, unavoidable and necessary to implement. Other items rated with an average higher than 4 were that introducing changes has a significant impact on increasing user satisfaction and that by introducing changes the institution gains in importance in the local community, whereas 
the claim that introducing changes has a significant impact on increasing user numbers received a lower rating. In all these cases the median and the mode had the value 4 . Thus, the respondents are mostly in agreement with the statement that changes implemented in their information institution have significant positive implications on the users and the community in which the institution operates.

A relatively high level of agreement, but lower than in previous cases, was shown by the surveyed professionals for the statement that the key role in change management is taken by the management of the institution. A similar rating was given to the claim that the institution's employees are actively involved in the process of changes, which can be seen as satisfactory from the viewpoint of change management. In relation to these two items, the statement that employees receive a clear explanation of the importance and purpose of changes being introduced was rated with lower scores.

All three measures of central tendency (mean, median and mode) show that respondents have a rather neutral attitude towards the following claims: in the process of changes, all parts of the institution are actively cooperating with each other; much attention is given to reducing resistance to change; changes are introduced according to a pre-set plan; and finally, the institution has devised a strategy for introducing changes. The lowest average rating was given to the statement that the employees who contribute most to the process of change are specially rewarded. It can be concluded that change management in Croatian information institutions must be given more attention than previously. The obtained results are particularly indicative if we take into account that managers, who have the biggest responsibility for changes in information institutions, dominated the sample.

Respondents were also asked to indicate, on a scale of 1 to 5 , how successful their institutions have been in managing change. The mean for this item was 3.46 with a standard deviation 1.01, while both the median and mode were 4 . These results are in accordance with the above satisfaction ratings for the five aspects of change (organisational changes, technical and technological changes, human resource changes, changes of the premises, and changes of the services offered) and imply that employees who participated in the study think that there is room for improving change management practice in their institutions.

A factor analysis was carried out on 14 variables that were related to the perception of different aspects of change management. The Kaiser-Meyer-Olkin measure of sampling adequacy, with the value of 0.855 , indicated that the data were adequate for a factor analysis. Bartlett's test of sphericity confirmed that the correlation matrix was not equal to the identity matrix $\left(\chi^{2}=1536.487, p<0.001\right)$, which suggested that the variables were correlated. With this, one more precondition for the factor analysis was satisfied.

A principal components analysis resulted in three subscales, accounting for 62.2 percent of the total variability observed. The number of factors was determined by means of the Kaiser's criterion (only those factors with eigenvalue higher than 1 were included). The varimax rotation was used to improve the interpretability of the solution. The obtained factor loadings, which represent correlations between factors and variables (Burn and Burns 2008; Taylor 2013), are shown in Table 3, along with the associated communalities. Factor loadings reflect the strength and direction of a relationship between underlying dimensions and items (Hawley and Little 2003), while communalities measure the proportion of variance in a given variable explained by all the factors (Hahs-Vaughn 2017). 
Dukić, G., Dukić, D. \& Kozina, G.

The item statements in Table 3 are sorted by the size of their factor loadings on each factor.

Table 3: Factor Loadings and Communalities

\begin{tabular}{|c|c|c|c|c|}
\hline \multirow{2}{*}{ Item statement } & \multicolumn{3}{|c|}{ Factor loadings } & \multirow{2}{*}{ Communalities } \\
\hline & Factor 1 & Factor 2 & Factor 3 & \\
\hline $\begin{array}{l}\text { In the process of changes, all parts of the } \\
\text { institution are actively cooperating with each } \\
\text { other }\end{array}$ & 0.820 & 0.163 & 0.088 & 0.707 \\
\hline $\begin{array}{l}\text { Changes are introduced according to a pre-set } \\
\text { plan }\end{array}$ & 0.801 & 0.131 & 0.063 & 0.663 \\
\hline $\begin{array}{l}\text { The institution has devised a strategy for } \\
\text { introducing changes }\end{array}$ & 0.781 & 0.212 & -0.025 & 0.655 \\
\hline $\begin{array}{l}\text { Employees receive a clear explanation of the } \\
\text { importance and purpose of changes being } \\
\text { introduced }\end{array}$ & 0.753 & 0.225 & 0.209 & 0.662 \\
\hline $\begin{array}{l}\text { Much attention is given to reducing resistance } \\
\text { to change }\end{array}$ & 0.731 & 0.157 & 0.149 & 0.581 \\
\hline $\begin{array}{l}\text { The employees who contribute most to the } \\
\text { process of change are specially rewarded }\end{array}$ & 0.642 & 0.058 & -0.023 & 0.417 \\
\hline $\begin{array}{l}\text { The institution's employees are actively } \\
\text { involved in the process of changes }\end{array}$ & 0.640 & 0.107 & 0.383 & 0.568 \\
\hline $\begin{array}{l}\text { The key role in change management is taken by } \\
\text { the management of the institution }\end{array}$ & 0.505 & -0.087 & 0.114 & 0.275 \\
\hline $\begin{array}{l}\text { Introducing changes has a significant impact on } \\
\text { increasing user numbers }\end{array}$ & 0.101 & 0.857 & 0.150 & 0.767 \\
\hline $\begin{array}{l}\text { Introducing changes has a significant impact on } \\
\text { increasing user satisfaction }\end{array}$ & 0.092 & 0.788 & 0.357 & 0.757 \\
\hline $\begin{array}{l}\text { By introducing changes the institution gains in } \\
\text { importance in the local community }\end{array}$ & 0.222 & 0.759 & 0.078 & 0.631 \\
\hline $\begin{array}{l}\text { Changes are necessary if the institution is to } \\
\text { survive and develop }\end{array}$ & 0.023 & 0.073 & 0.812 & 0.665 \\
\hline $\begin{array}{l}\text { Changes are inextricably connected with the } \\
\text { work and activities of the institution }\end{array}$ & 0.172 & 0.175 & 0.796 & 0.694 \\
\hline $\begin{array}{l}\text { Changes contribute to improving an } \\
\text { institution's efficiency and effectiveness }\end{array}$ & 0.186 & 0.379 & 0.695 & 0.661 \\
\hline
\end{tabular}

The first factor explained 30.3 percent of the variance. This dimension comprised eight items: in the process of changes, all parts of the institution are actively cooperating with each other; changes are introduced according to a pre-set plan; the institution has devised a strategy for introducing changes; employees receive a clear explanation of the importance and purpose of changes being introduced; much attention is given to reducing resistance to change; the employees who contribute most to the process of change are specially rewarded; the institution's employees are actively involved in the process of 
changes; and finally, the key role in change management is taken by the management of the institution. The stated variables refer to the principles and application of change management in the information institution. Therefore, it makes sense to call the first factor "Change management practice".

There are three items that make up the factor "Impact of change", which accounts for 16.4 percent of the variance. This dimension includes the following statements: introducing changes has a significant impact on increasing user numbers; introducing changes has a significant impact on increasing user satisfaction; and by introducing changes the institution gains in importance in the local community.

The factor "Necessity of change" accounts for 15.5 percent of the variance and comprises the following items: changes are necessary if the institution is to survive and develop; changes are inextricably connected with the work and activities of the institution; and changes contribute to improving an institution's efficiency and effectiveness.

Within the analysis, the factor scores for each respondent were also calculated. Factor scores are standardized and represent composite measures that provide information about an individual's placement on the factor (DiStefano, Zhu and Mîndrilă 2009). Therefore, the positive value of the factor score indicates that the individual scores are above the average of all responses, and vice versa (Cleff 2013). The factor scores for the three determined factors and four socio-demographic characteristics (gender, age, institution type and position in the management structure) were entered in the ordinal logistic regression model as independent variables. Assessment of the institution's success in managing change was defined as a dependent variable. As previously stated, ordinal regression analysis was applied to explore the relationship between the outcome and predictor variables.

Since higher values of the dependent variable were more probable, a complementary loglog link function was used in the analysis. To justify the use of a complementary log-log link function, it was first necessary to test the model's adequacy. In this context, the chi-square statistic indicated that the explanatory variables add significant predictive capacity beyond the baseline intercept-only model $\left(\chi^{2}=141.662, p<0.001\right)$. The overall goodness of fit was also evaluated using the Pearson's chi-square statistic for the model and the chi-square statistic based on the deviance. These two statistics aim to provide evidence on whether the observed data is inconsistent with the fitted model (McCormick et al. 2017). According to the results, the data and the model predictions were similar $\left(\chi^{2}=539.184, p=1.000\right)$, which confirmed the model's validity.

The coefficient of determination, as a measure of the proportion of variance explained by the model, is a commonly used statistic in linear regression analysis. However, dependent variable in ordinal logistic regression is not continuous and the total sum-of-squares is not equal to the regression sum-of-squares plus the residual sum-of-squares. As a consequence, the coefficient of determination cannot be directly transferred from a linear regression model. For this reason, several pseudo $\mathrm{R}^{2}$ statistics for the ordinal logistic regression model have been developed (Coxe, West and Aiken 2013; Tabachnick and Fidell 2013; Finkbeiner 2017). The Cox and Snell, Nagelkerke and McFadden pseudo $R^{2}$ statistics for the present model were acceptable at $0.443,0.478$ and 0.223 , respectively.

Table 4 contains parameter estimates for the model and Wald statistics with their corresponding significance levels. Wald statistics represent a measure of the statistical 
significance of individual coefficients (Menard 2002). A higher Wald chi-square indicates a greater impact on the outcome variable. The Wald test is used to test the hypothesis that the regression coefficient is equal to zero (Kleinbaum and Klein 2010). The p-values associated with the Wald statistics are reported in the last column of Table 4.

Table 4: Parameter Estimates for the Ordinal Logistic Regression Model and Results of the Wald Test

\begin{tabular}{|c|c|c|c|c|c|c|}
\hline & \multirow{2}{*}{$\begin{array}{l}\text { Estimated } \\
\text { coefficient }\end{array}$} & \multirow{2}{*}{$\begin{array}{l}\text { Standard } \\
\text { error }\end{array}$} & \multicolumn{2}{|c|}{$\begin{array}{l}\text { 95\% Confidence } \\
\text { interval }\end{array}$} & \multirow{2}{*}{$\begin{array}{l}\text { Wald } \\
\text { statistic }\end{array}$} & \multirow{2}{*}{$\begin{array}{l}\text { Significance } \\
\text { (p-value) }\end{array}$} \\
\hline & & & $\begin{array}{l}\text { Lower } \\
\text { bound }\end{array}$ & $\begin{array}{l}\text { Upper } \\
\text { bound }\end{array}$ & & \\
\hline \multicolumn{7}{|l|}{ Threshold } \\
\hline Success in managing change $=1$ & -2.711 & 0.528 & -3.745 & -1.676 & 26.373 & 0.000 \\
\hline Success in managing change $=2$ & -1.379 & 0.482 & -2.323 & -0.435 & 8.194 & 0.004 \\
\hline Success in managing change $=3$ & -0.217 & 0.471 & -1.140 & 0.706 & 0.212 & 0.645 \\
\hline Success in managing change $=4$ & 1.796 & 0.480 & 0.855 & 2.737 & 13.987 & 0.000 \\
\hline \multicolumn{7}{|l|}{ Location } \\
\hline $\begin{array}{l}\text { Factor } 1 \text { (Change management } \\
\text { practice) }\end{array}$ & 0.807 & 0.100 & 0.612 & 1.002 & 65.703 & 0.000 \\
\hline Factor 2 (Impact of change) & 0.367 & 0.082 & 0.208 & 0.527 & 20.310 & 0.000 \\
\hline Factor 3 (Necessity of change) & 0.036 & 0.080 & -0.121 & 0.194 & 0.202 & 0.653 \\
\hline Age (years) & -0.003 & 0.008 & -0.018 & 0.013 & 0.098 & 0.754 \\
\hline \multicolumn{7}{|l|}{ Gender } \\
\hline Female & 0.270 & 0.198 & -0.118 & 0.657 & 1.854 & 0.173 \\
\hline \multicolumn{7}{|l|}{ Male (reference category) } \\
\hline \multicolumn{7}{|l|}{ Institution type } \\
\hline Library & 0.587 & 0.321 & -0.043 & 1.217 & 3.334 & 0.068 \\
\hline Museum & 0.409 & 0.328 & -0.235 & 1.053 & 1.550 & 0.213 \\
\hline \multicolumn{7}{|l|}{ Archive (reference category) } \\
\hline \multicolumn{7}{|l|}{ Position } \\
\hline Manager & -0.114 & 0.171 & -0.450 & 0.222 & 0.443 & 0.506 \\
\hline Employee (reference category) & & & & & & \\
\hline
\end{tabular}

The results suggest that the first and second factor have a significant effect on the assessment of the institution's success in managing change. On the contrary, the third factor and all socio-demographic characteristics contribute little to the model. According to the estimated coefficients, attitudes towards change management practice influence perception of the institution's success in managing change more than attitudes towards the impact of change. Both coefficients are greater than zero, indicating a significantly positive relationship with the outcome variable. It can be concluded that employees who highly rate change management practice and are aware of the impact of change tend to value achievements in managing change more positively. Hence, a greater institution's commitment to various aspects of change management and pointing out the benefits of change will foster employees' satisfaction and result in their more favourable perception. Although it could be expected, employees' awareness of the necessity of change is not significantly related to the dependent variable. Gender and institution also seem not to be important predictors of the outcome, but since there are categories that are marginally significant, it is advisable to keep them in the model. 


\section{CONCLUSION}

A number of factors, and particularly ICT development, have had a strong impact on the functioning of information institutions. More than ever before, libraries, museums and archives are facing a variety of challenges. The environment in which they are active has high expectations and puts numerous requirements on information institutions. The only logical response in such a situation is adaptation, which in itself means change. However, changes should not be undertaken in an impromptu manner, as their effects might in that case be worse than leaving the status quo. On the contrary, any change must be carefully thought out and designed, and its implementation prudently managed and controlled. Throughout this process, particular attention should be given to human resources.

The intention of the present study was to establish to what extent the professionals from Croatian information institutions were satisfied with the changes implemented in their organisations and how they perceived different aspects of change management. Furthermore, the research sought to determine the factor structure of the items representing their attitudes and to examine the influence of the identified factors and socio-demographic characteristics on perceived success in managing change. For the most part, the professionals who participated in the survey were mildly supportive of the changes that took place in their institution. This result suggests that there is much room for improvement when it comes to change management. Such a conclusion is further confirmed by the respondents' assessment of the institution's success in managing change. On the positive side, the study revealed that professionals employed in libraries, museums and archives were aware of the importance and necessity of change. Usually, resistance to change is one of the biggest obstacles for management trying to implement changes. It is therefore an asset to have this positive attitude of employees. However, it should be noted here that the sample consisted predominantly of persons with a managerial role, which probably reflected in the results.

An explanatory factor analysis, which was used to reduce the number of observed variables and to identify the latent constructs, resulted in three factors: "Change management practice", "Impact of change" and "Necessity of change". They represent the underlying dimensions of employees' perceptions of change and their assessments of change management. Ordinal logistic regression analysis revealed that the first and second factor significantly affect the way employees perceive the institution's success in managing change, while the third factor, as well as gender, age, institution type and position in the management structure appear to be weakly related to the outcome. Since attitudes towards change management practice and impact of change positively influence employees' perception, more attention should be devoted to these issues. Accordingly, the results imply that libraries, museums and archives must strive to continuously improve change management practice and emphasize the importance of change.

Due to the complexity and dynamics of today's environment and the specific role of information institutions in the society, it is necessary to stimulate the change management research in such organizations. Experts from different fields, including information professionals, organisational and technical specialists, psychologists and engineers, have to be involved in the research process, as this would ensure a comprehensive, interdisciplinary approach to change management issues. In order to improve efficiency and effectiveness of information institutions, it is crucial to understand how change management is perceived and to identify the factors that influence its implementation. By 
Dukić, G., Dukić, D. \& Kozina, G.

addressing these questions, this study contributes to the theory and practice of change management.

\section{ACKNOWLEDGEMENT}

This research received no specific grant from any funding agency in the public, commercial, or not-for profit sectors.

\section{REFERENCES}

Adeyoyin, S. O., Imam, A. and Bello, T. O. 2012. Management of change in the 21st century libraries and information centres. Library Philosophy and Practice (e-journal). Paper 695. Available at: http://digitalcommons.unl.edu/libphilprac/695

Ammons-Stephens, S., Cole, H. J., Jenkins-Gibbs, K., Riehle, C. F. and Weare, W. H. Jr. 2009. Developing core leadership competencies for the library profession. Journal for Library Leadership and Management, Vol. 23, no. 2: 63-74.

Anderson, D. and Anderson, L. A. 2010. Beyond change management: How to achieve breakthrough results through conscious change leadership. (2nd ed.). San Francisco: Pfeiffer.

Anderson, R. J. 1985. Managing change and chance: Collecting policies in social history archives. American Archivist, Vol. 48, no. 3: 296-303.

Aparac-Jelušić, T. 2005. The Bologna process and information sciences studies. Paper presented at the Professional Conference of Union of Associations of Slovene Librarians, Portorož, Slovenia, 24-26 October 2005.

Atkin, B. and Brooks, A. 2009. Total facilities management. (3rd ed.). Chichester: WileyBlackwell.

Bartlett, J. A. 2012. New and noteworthy: The heart and soul of change management. Library Leadership \& Management, Vol. 26, no. 1: 1-4. Available at: http://journals.tdl.org/IIm/index.php/IIm/article/download/6168/5816

Biswas, S. C. 2012. Managing libraries in the 21st century: Some important trends. Paper presented at the National Seminar on Challenges in Library Management System (CLMS 2012), Kolkata, India, 24-25 February 2012.

Borgman, C. L. 2002. Challenges in building digital libraries for the $21^{\text {st }}$ century. Paper presented at the 5th International Conference on Asian Digital Libraries (ICADL 2002), Singapore, 11-14 December 2002.

Buchanan, K. 2012. Change management in the information and referral industry. Feliciter, Vol. 58, no. 3: 108-109.

Burns, R. B. and Burns, R. A. 2008. Business research methods and statistics using SPSS. Los Angeles: Sage.

Carnall, C. 2007. Managing change in organizations. (5th ed.). Harlow: Financial Times Prentice Hall.

Cleff, T. 2013. Exploratory data analysis in business and economics: An introduction using SPSS, Stata, and Excel. Cham: Springer Science \& Business Media.

Coxe, S., West, S. G. and Aiken, L. S. 2013. Generalized linear model. In: T. D. Little, ed. The Oxford handbook of quantitative methods, Vol. 2: Statistical analysis. Oxford: Oxford University Press: 26-51.

Croatian Bureau of Statistics. 2012. Statistical yearbook of the Republic of Croatia 2012. Zagreb: Croatian Bureau of Statistics. 
DiStefano, C., Zhu, M. and Mîndrilă, D. 2009. Understanding and using factor scores: Considerations for the applied researcher. Practical Assessment, Research \& Evaluation, Vol. 14, no. 20: 1-11.

Dole W. A. 2013. What's all this I hear about core competencies for library planning and assessment? Journal of Library Administration, Vol. 53, no. 7-8: 472-481.

Dukić, G. 2015. Perception and adoption of change management in information institutions: A study from Croatia. Libri, Vol. 65, no. 3: 175-190.

Farrow, J. 1997. Management of change: Technological developments and human resource issues in the information sector. Journal of Managerial Psychology, Vol. 12, no. 5: 319324.

Finkbeiner, P. 2017. Social media for knowledge sharing in automotive repair. Cham: Springer.

Fisher, W. 2001. Core competencies for the acquisitions librarian. Library Collections, Acquisitions, and Technical Services, Vol. 25, no. 2: 179-190.

Griffith-Cooper, B. and King, K. 2010. The change readiness rubric. In: R. Watkins, and D. Leigh, eds. Improving performance in the workplace, Vol. 2: Selecting and implementing performance interventions. Silver Spring: International Society for Performance Improvement: 392-417.

Hahs-Vaughn, D. L. 2017. Applied multivariate statistical concepts. New York: Routledge.

Hawley P. H. and Little T. D. 2003. Modeling intraindividual variability and change in biobehavioral developmental processes. In B. H. Pugesek, A. Tomer, and A. von Eye, eds. Structural equation modeling: Applications in ecological and evolutionary biology. Cambridge: Cambridge University Press: 143-170

Institute of Museum and Library Services. 2009. Museums, libraries, and 21st century skills (IMLS-2009-NAI-01). Washington, DC: Institute of Museum and Library Services.

Kamila, K. 2013. Impact of ICT on the changing roles of the librarian, other library and information science (LIS) professionals, and managerial change. In: T. Ashraf, and P. A. Gulati, eds. Design, development, and management of resources for digital library services. Hershey: Information Science Reference (an imprint of IGI Global): 328-341.

Kleinbaum, D. G. and Klein, M. 2010. Logistic regression: A self-learning text. (3rd ed.). New York: Springer.

Konings, K. and Dekker, R. 2005. Strategy and change management in Delft University of Technology Library. New Review of Information Networking, Vol. 11, no. 1: 109-121.

Lasić Lazić, J. 2010. Information institutions for the 21st century. Paper presented at the 4th International Conference "European Guidelines for Cooperation of Libraries, Archives and Museums", BAM 2010, Sarajevo, Zenica, Bosnia and Herzegovina, 12-13 November 2010.

Lientz, B. P. and Rea, K. P. 2004. Breakthrough IT change management: How to get enduring change results. Amsterdam: Elsevier Butterworth-Heinemann.

McCormick, K., Salcedo, J., Peck, J. and Wheeler, A. 2017. SPSS Statistics for data analysis and visualization. Indianapolis: John Wiley \& Sons, Inc.

Menard, S. 2002. Applied logistic regression analysis. (2nd ed.). Thousand Oaks: Sage.

Molaudi, M. M. and Du Toit, A. S. A. 2003. Management of change in academic information services. Mousaion, Vol. 21, np. 1: 82-95.

Nazim, M. and Mukherjee, B. 2013. Knowledge management competencies required among library and information science professionals: An Indian perspective. Library Review, Vol. 62, no. 6/7: 375-387.

Pandya, C. and Pandya, S. 2010. The contemporary changes in the current scenario: Change management in the libraries and information centres. Paper presented at the 7th Convention PLANNER - 2010, Tezpur, India, 18-20 February 2010. 
Partridge, H. Menzies, V., Lee, J., and Munro, C. 2010. The contemporary librarian: Skills, knowledge and attributes required in a world of emerging technologies. Library \& Information Science Research, Vol. 32, no. 4: 265-271.

Paton, R. A. and McCalman, J. 2008. Change management: A guide to effective implementation. (3rd ed.). Los Angeles: SAGE.

Penfold, S. 2000. Information warriors in the 21st century: Managing change for information services. Business Information Review, Vol. 17, no. 1: 34-42.

Rasuli, B. and Naghshineh, N. 2014. Digital library education in Iran: Perspectives of Library \& Information Science educators and academic librarians. Malaysian Journal of Library \& Information Science, Vol. 19, no. 3: 51-65.

Robati, A. P. and Singh, D. 2013. Competencies required by special librarians: An analysis by educational levels. Journal of Librarianship and Information Science, Vol. 45, no. 2: 113-139.

Ruben, B. D. 1993. Integrating concepts for the information age: Communication, information, mediation, and institutions. In: J. R. Schement, and B. D. Ruben, eds. Between communication and information, Vol. 4: Information \& Behavior, New Brunswick: Transaction Publishers: 219-236.

Sandell, R. 2003. Social inclusion, the museum and the dynamics of sectoral change. Museum and Society, Vol. 1, no. 1: 45-62.

Shah, N. and Harris, P. T. 2010. Using change management to support stakeholder management. In: E. Chinyio, and P. Olomolaiye, eds. Construction stakeholder management. Chichester: Wiley-Blackwell: 338-349.

Sharma, R. R. 2008. Change management: Concepts and applications. New Delhi: Tata McGraw-Hill.

Singh, V. and Mehra, B. 2013. Strengths and weaknesses of the Information Technology curriculum in Library and Information Science graduate programs. Journal of Librarianship and Information Science, Vol. 45, no. 3: 219-231.

Smiraglia, R. 2014. Cultural synergy in information institutions. New York: Springer.

Storey, C. 1995. The impact of information technology on management and organization: The case of Hong Kong Polytechnic University Library. Library Management, Vol. 16, no. 2: 22-33.

Suchy, S. 2004. Leading with passion: Change management in the 21st-century museum. Walnut Creek: Altamira Press.

Tabachnick, B. G. and Fidell, L. S. 2013. Using multivariate statistics. (6th ed.). Boston: Pearson.

Tam, L. W. H and Robertson, A. C. 2002. Managing change - libraries and information services in the digital age. Library Management, Vol. 23, no. 8/9: 369-377.

Taylor, C. S. 2013. Validity and validation. Oxford: Oxford University Press.

Thomas, V. K., Satpathi, C. and Satpathi, J. N. 2010. Emerging challenges in academic librarianship and role of library associations in professional updating. Library Management, Vol. 31, no. 8/9: 594-609.

Weldon, E. 1983. Archives and the challenges of change. American Archivist, Vol. 46, no. 2: 125-134. 